\title{
The Localization Industry: A Profile of DNA Media ${ }^{1}$
}

Dianne Cyr, (E-mail:cyr@techbc.ca), Technical University of British Columbia Richard Lew, (email: rlew3@yahoo.com), Technical University of British Columbia

\begin{abstract}
Since the mid-1990s the e-commerce industry experienced dramatic growth that was only the start of a business revolution. With the rapid expansion of Internet related infrastructure equipment and services that allowed low-cost global communications, the beginnings of a truly global economy began to take shape. Riding on the coat tails of this wave was software and content localization services that were a necessary component in selling products and services to different countries and across many cultures. The challenges of operating in a diverse, multicultural market are great, filled with cultural subtleties that can be a minefield for the uninformed. DNA Media, based in Vancouver, Canada, is a software localization company specializing in language, software application and content (Web-based technologies, application design, CD-ROM, DVD and multimedia versioning). The company enjoyed strong growth in its services in the last two years and, by the year 2000 it was in a position to expand rapidly. This case provides insight into how managers of a small but growing information technology company managed its growth, established its market in the software localization industry, and planned for the next phase of expansion.
\end{abstract}

\section{Introduction}

It was another rainy day in Vancouver. Looking out his window towards the mountains on the North Shore, Steven Forth, CEO of DNA Media reflected on some of the decisions his management team had made over the last few years. Was the organizational restructuring in 2000 the right move, and are the recent expenditures on technology and people really going to pay off by 2003 ? This afternoon he will meet with his senior management team to discuss the projected Q1 2001 business performance and plans to meet their 2003 business targets.

Steven's thoughts were preoccupied with this year's turmoil in the stock market for high technology companies. The NASDAQ index peaked during the first quarter of 2000 prompting Alan Greenspan, the Chairman of the US Federal Reserve Board, to warn investors of "market over exuberance" and rising interest rates. The high technology sector crashed suddenly in April and continued its downward spiral for the remainder of the year. It seems the "get-rich-quick" bubble for Internet companies with stratospheric P/E ratios was coming to an end. Raising equity financing from venture capitalists to grow his company will be difficult, with increased investor scrutiny on the business model and corporate performance.

Nonetheless, the downturn in the high technology industry will have direct implications for DNA Media. DNA is in the localization business. Localization refers to content adaptation to accommodate various cultures and cultural preferences. This includes language translation and adjusting content to capture the meaning of the message, as well as consideration of various web design features such as the use of appropriate colors, navigation tool preferences etc. For instance, the use of certain colors may be offensive in one culture and perfectly acceptable in another. In Asia, white is associated with death, while purple is associated with death and funeral parlors by the French. On a more technical note, the practice of using "cookies" to track Internet users is well-established in North America for Internet marketing, but the use of this technology is illegal under France's privacy laws.

According to Mick McCallister, localization is generally "not an information dissemination issue". Localization is a business that is very strongly driven by marketing, and the globalization of trade. If a customer is choosing between two comparably priced printers with similar functionality and capabilities being sold in Lebanon, for example,

\footnotetext{
${ }^{1}$ The authors sincerely appreciate the participation of Steven Forth, Jim Eagles, Mick McCallister and Andrew Wilson at DNA Media for their insights and time contributed to this project. Financial support for this project was provided by the Technical University of British Columbia.
} 
which one will he or she choose? Even though most people looking to buy a computer in Lebanon are able to read English, localization affects buyer's preferences. Marketing studies have shown that the consumer will more likely purchase the printer that comes with an Arabic manual despite the fact that he or she is able to read English fluently. The person makes the buying choice based on localized marketing, not because localization is a necessary service for the purchase. The return on investment for localization services is immediate and can be substantial if done properly.

Given globalization, and the shake up in the high tech arena, businesses involved in the software localization industry are strongly affected. Many of DNA's valued clients are high technology companies, and no one knows how long this downturn will last. This set of events was not surprising to Steven, since his sales staff and many of his competitors were scrambling to find and retain clients over the last few months. The year 2000 just closed, marking the real beginning of the new millennium. "What a way to start the year and the new century", thought Steven. How should DNA Media respond in light of these recent developments, and will it change his company's four-year strategic plan that started in 1999? Small companies, like DNA Media, with limited financial resources are under increasing price and service pressures from larger competitors. What strategy must DNA Media adopt to grow the company? He closed his eyes, rubbed his temples and began thinking and smiling, "Life would have been easier if I listened to my mother and had become a professor".

\section{DNA Background and Beginnings}

DNA Media is a small-to-medium sized software localization firm employing approximately 60 people (45 in Vancouver and 15 in Japan). They are experts in providing localization services in software application development, multimedia technologies (CD-ROM, DVD), versioning for broadcasters and recording studios and in software design and engineering services. For North Americans, almost all modes of communication are done in English and localization services are not well appreciated as in non-English speaking countries. Whenever one reads information, whether from a computer, television or written manual, information is forwarded and subsequently interpreted by the reader. Communication is a key element in performing global business, and DNA Media provides a valued service that ensures the intended audience receives the "right" message. This task is achieved by taking advantage of specific knowledge about cultures and languages, and then applying this know-how in various electronic-based media. Andrew Wilson, the VP of Business Development, described the company as a "professional localization services company specializing in a smaller number of languages, internationalization and engineering. We are not the lowest priced firm, but we are price competitive."

The company is headquartered in Vancouver and was founded by Steven and two partners in 1989. Within a decade, Steven grew the business from a home-based operation into one of the leading and most respected localization companies in Canada. The company specializes in Asian languages and computer / multimedia applications, which play to the strengths of DNA Media's location, the background of its founders and the skills of its employees. Steven attributes the early success of the company to the early adoption of advanced computer and telecommunication equipment like faxes to manage projects and to coordinate workflow with his clients. All the executives are fully bilingual, and English only became the official language at work after the company had grown to over 10 employees. The unique multi-cultural environment makes the company distinct from most North American companies. There have also been significant challenges, and even with the company's growth, market pressures have forced the company to re-invent itself on a number of occasions. Appendix 1 outlines a full chronology of the development of the company, while Appendix 2 profiles the DNA's structure.

The company has come a long way. When Steven first started the company, he did not have a business plan. Now DNA Media has a mission to be one of the world leaders in providing multilingual production and content management. Senior management have targeted revenues to increase from $\$ 1.7$ million (1998) to \$10.4 million (2003), and net profit to increase from a modest loss (1998) to 10 percent (2001). DNA Media is mid-way through the revenue growth plan, but with the recent meltdown in the Internet industry revenues are falling behind the plans. A major constraint for the company is the lack of financial resources, which affects the number and quality of workers needed for the business.

Historically DNA has either been debt financed or financed out of the owners' pockets. There are advantages to this strategy. As Jim Eagles at DNA explains, "equity capital, as opposed to debt financing, allows companies to operate with losses with the promise of future growth and profits." In effect, debt financing requires interest payments, thereby reducing cash flow that might otherwise be used to grow the company. 
However, choosing to avoid equity financing during 1996 to 1999 hurt the company's growth. Spreading its resources too thinly and providing too many types of services has also worked against the company in attracting equity financing. Since the early years, DNA Media has tried to improve its attractiveness to local venture capitalists by restructuring the company, by being very focused on its most profitable core businesses, and by closing its unprofitable multi-media (CD-ROM) productions division in 2000.

Growing the company has been an expensive proposition. Money was invested into upgrading software tools, and internal accounting and project management systems. Effective marketing is a critical factor, and historically has been done by Steven attracting business through word-of-mouth, cold calling, and networking - rather than by advertising. Located in Vancouver and Japan limited the company's access to most of its larger clients in Eastern Canada and in the U.S., often requiring expensive and time-consuming flights across the country to meet with clients face-to-face. To balance these costs, a modestly valued Canadian dollar makes services more economical to American firms. Additionally, by paying employees in Canadian funds, DNA Media has an advantage over American based operations offering comparable services.

Steven firmly believes DNA Media's business strength relates to five key factors, and he does not think this will change in the foreseeable future. These include: capabilities such as expertise and resources to localize in the desired culture and language; quality of interaction and relationship between developer and vendor and ability to facilitate partnerships; vendor reputation; project management expertise; and rapid turnaround time which is especially important for software services.

\section{Localization Market Opportunities}

Despite all the negative news about the high technology industry, DNA Media seems to be in the right spot at the right time. Localization services are growing all over the world at a very fast pace, especially with the widening demand for advanced communications driven by the globalization of information and business. Demographics and business globalization has forced the rest of world to adopt new technologies like the Internet, wireless networks, global communications and computers. According to eMarketer ${ }^{2}$, even though over 61 percent of world users of the Internet are from the USA in 1998, this will decline to 37 percent by 2002. Demand for globalization and localization services will increase. How localization will be performed and in which language will be another issue. According to Sapient Globalization Report there are over 6,700 living languages in the world; the fifteen most popular languages are spoken by 49.5 percent of the world's population, while the other 51.5 percent of the world's population speak 6,600 languages. ${ }^{3}$ Yet, only about 6 percent of the world's population speak English. ${ }^{4}$

As reliance on communications increases as part of the information lifestyle via the Internet (including wireless devices and pagers), localization needs and service demand will increase. The adoption by the general population of increasingly higher levels of communication and database technology means that the user interfaces must become easier to use and more highly adapted to local conditions. This is a vital market and recently completed work by DNA Media with Nikon on user interfaces for consumer devices confirms this.

Media versioning is also an important market for localization services. The explosive growth of DVD and interactive-media like the Internet and WebTV all require some level of localization for global markets. For many years DNA Media has been involved in media versioning of movie productions and the Internet, and has the expertise to grow in this market.

The actual size of the localization market is debatable, and at times, quotes from industry leaders are con-

${ }^{2}$ Emarketer (1998). The eOverview Report, San Francisco.

${ }^{3}$ LISA Newsletter, (2000). The Post-Localization Era: The Best is Yet to Come! Keynote speech by Roger Jeantry, 9(4).

${ }^{4}$ Richards De Wit, S. (2001). Going Global with Your Online Presence Requires More than Just Quick Translation. Business in Vancouver, January, 23-29. 
tradictory. The CEO of Bowne Global Services recently stated that the market is "growing at approximately 30 percent annually". Mark Homnack, the CEO of SimulTrans, does not believe the market is as big as many reports suggest, and that growth projections are being promoted to hype up stock prices. ${ }^{6}$ Table 1 illustrates the generally held market sales expectation.

Table 1 Revenues from Localization Services (in US dollars) ${ }^{5}$

\begin{tabular}{|c|c|c|c|}
\hline & $\mathbf{1 9 9 5}$ & $\mathbf{1 9 9 7}$ & $\mathbf{2 0 0 0}$ (projected) \\
\hline Globalization & $\$ 1,700,000,000$ & $\$ 2,800,000,000$ & $\$ 6,260,000,000$ \\
\hline $\begin{array}{c}\text { Software localiza- } \\
\text { tion }\end{array}$ & $\$ 561,000$ & $\$ 1,100,000,000$ & $\$ 2,380,000,000$ \\
\hline $\begin{array}{c}\text { Japanese localiza- } \\
\text { tion }\end{array}$ & $\$ 101,000$ & $\$ 322,000$ & $\$ 737,000$ \\
\hline
\end{tabular}

\section{Threats to the Localization Industry}

Technology has the potential to disrupt the industry. Translation software and technology developments will affect how the localization process takes place in the future. "Open" standards are an increasingly critical factor that can move the industry away from proprietary translation technologies that some industry insiders have suggested are hurting the growth of the industry. DNA Media is a strong supporter of open standards. By moving toward open-standards, translation costs may be reduced by decreasing reliance on expensive proprietary software solutions, making services more affordable and growing a localization market for small-to-medium sized enterprises.

Further, the power of the buyer is very strong. The top ten industry leaders like IBM, Microsoft, Hewlett Packard and Oracle make up about 50 percent of the market for localization services. Although revenues from services appear significant, large clients have the power to squeeze the margins of localization service companies. Some companies have not been able to make any profit upon completion of projects for these large clients. This revelation has significant implications for DNA Media that not only faces the same business problems as the larger players, but must also have a survival plan as a small fish in what now appears to be a smaller pond.

As the world increases its use of computers for consumer and business, the demand for industry-specific productivity software for particular industries (e.g. medical, training, etc.) will also increase. Augmented software product complexity means localization becomes increasingly complicated; forms higher barriers to entry; and increases demand on localization firms. In addition, the ability to attract and retain talented people is becoming more competitive. Not only is it becoming more difficult to attract talent, but also more talented people will be needed to perform increasingly complicated localization projects. As such, the growth of the localization industry will be limited by the supply of skilled people. Andrew Wilson at DNA Media notes that, "unlike computer programmers that can be mass produced in schools, skilled localization people are very difficult to find and the necessary quality and range of skills needed by companies in the industry takes years to develop."

\section{The Consolidation Enigma}

Consolidation was a strategy to increase the profitability of a fragmented industry. The first wave of consolidation (starting in 1996) involved Silicon Valley computer translation companies - merging localization services with technical communications. These large, consolidated IT-based localization companies initially tried to offer translation services as a commodity through computerized translation. The complexity and dynamic nature of language has limited the overall success of this strategy. In 1999, some of the large consolidated companies shifted

\footnotetext{
${ }^{5}$ Pinkus, C.A. (1998). Speech at the Bowne Annual General Meeting, March 27.

${ }^{6}$ LISA Newsletter (2000). The Future of Globalization Technology: Is it the Graveyared? Interview with Mark Homnack, 9(4).
} 
gears and began a more focused full-service marketing strategy. ${ }^{7}$ Consolidators attempted to develop worldwide networks to service global software developers. Basically, the consolidators took one of two approaches:

(1) "One Stop Shopping". Localization companies target international "global" software developers like Microsoft, Lotus, Oracle, SAP, and IBM that require translations in 20 or more languages. These localization companies became known as Multiple Language Vendors (MLV) with offices around the world. Even though small localization shops can promise better expertise and higher quality of work, large client companies will have a difficult time managing the project if work is contracted to over 20 different independent language vendors. The key added-value component of the MLV's is project management.

(2) Services for specific software applications. For example, one localization firm Lionbridge targets Financial Applications, Operating Systems and Web Technologies. Lionbridge recognized the need to improve content and project management of localization services, and focused on developing and selling tools for managing client and vendor workflow. This technology has helped smaller firms win contracts with large companies willing to outsource to more than one vendor.

As the industry matures, consolidation continued during 2001, as well-financed larger companies targeted the buyout of financially troubled smaller companies with valuable assets and skilled workers. The partnering of translation technology (globalization) with content management companies will be a natural fit. It is expected these types of alliances and mergers will drive the localization industry during the new millennium.

Although DNA Media competes with the large consolidators for contracts, the consolidators are also DNA's clients. Larger companies have outsourced jobs to DNA Media where the smaller company can perform more efficiently or has special language or technical expertise. The large consolidated companies do not see DNA Media as an immediate threat, but this may change in the future if DNA Media grows. DNA Media's direct smallmedium sized competitors are facing the same challenges in growing their businesses. DNA Media, however, has a good reputation with SE Asian languages and has expertise in multi-media and software engineering technologies.

Traditional translation companies who invested too heavily in technologies like computerized translations without clearly thinking about their business needs would be hard hit by the downturn in the stock market. Even though DNA Media has invested heavily over the last few years to increase its technological capabilities and to improve its profit margin, the investments were on project management and content management tools designed to complement and improve the operational efficiency of DNA's staff. From this point of view, DNA Media has the internal technical infrastructure for its next growth period.

Five large companies arose primarily from consolidation in the mid-1990s and dominate the industry. Appendix 4 summarizes the general characteristics for the software localization industry, and Appendix 5 profiles the key players. Companies such as Bowne Global Service, Alpnet or Lionbridge offer a wider range of languages and technology services, and are better able to invest in new technologies than smaller companies.

In 1996 Steven felt his company was uniquely positioned in the market, was growing quite well on its own, and that not much would be gained from consolidation. In hindsight, Steven wondered whether he might have at least tried to raise equity capital to finance his company's growth when the market was hot, instead of relying on debt financing. As a result, DNA is a much smaller player than companies that decided to consolidate. Table 2 compares the major consolidated companies with DNA Media.

\section{Table 2 Comparison of Large Consolidators and DNA Media in 1997 Source: Edward Person, August $1998^{8}$}

\footnotetext{
${ }^{7}$ Appendix 3 profiles the evolution and challenges of the localization industry.
}

\footnotetext{
${ }^{8}$ Person, E. (1998). A Strategic Analysis of a Software Localization Company", Unpublished MBA thesis, Simon Fraser University.
} 


\begin{tabular}{|l|c|c|c|c|c|}
\hline Company & $\begin{array}{l}\text { \# of } \\
\text { Countries }\end{array}$ & $\begin{array}{l}\text { Staff } \\
\text { Level }\end{array}$ & $\begin{array}{l}\text { Languages } \\
\text { offered }\end{array}$ & $\begin{array}{l}\text { 1997 Revenues } \\
\text { (US) attributed } \\
\text { to software lo- } \\
\text { calization }\end{array}$ & Market Capitalization (1997) \\
\hline Alpnet & 14 & 475 & 40 & $\$ 40,800,000$ & $\$ 95 \mathrm{~m}$ \\
\hline Berlitz & 35 & N/A & 200 & $\$ 80,500,000$ & $\$ 265 \mathrm{~m}$ \\
\hline $\boldsymbol{B G S}$ & $>7$ & $>700$ & N/A & $\$ 71,000,000$ & $\$ 768 \mathrm{~m}$ \\
\hline $\begin{array}{l}\boldsymbol{L} \boldsymbol{H} \boldsymbol{H} \text { Men- } \\
\boldsymbol{d e z}\end{array}$ & 25 & N/A & $>20$ & $\$ 31,600,000$ & $\$ 2,629 \mathrm{~m}$ \\
\hline Lionbridge & 7 & 350 & N/A & N/A & N/A \\
\hline $\boldsymbol{D N A}$ & 2 & 50 & 8 & $\begin{array}{c}\$ 1,700,000 \\
(\mathrm{Cdn})\end{array}$ \\
\hline
\end{tabular}

To date competitive rivalry amongst industry players is only moderate, and has facilitated the general expansion of the industry since there is currently enough work for everyone. However, if consolidation increases or when the industry matures further, competition will increase. This will place pressure on smaller companies such as DNA Media that have limited resources and a narrower range of services. Again, talented personnel are one of those scarce resources. Mick McCallister at DNA Media and a localization practitioner for almost 20 years adds, "Localization assets are highly intangible; they are people expertise. People are not assets that can be bought and sold. Clients don't have to do business with you just because you bought the company. After a merger, you can't buy people or the clients, and hardware is a depreciating asset. The localization industry sells potential; revenues are not a promise that can be reached every year."

Smaller companies may be unable to compete with larger players based on price and range of services. Jim Eagles, the COO of DNA Media, observes that a unique characteristic about this industry is that "it acts like a mature industry yet has no economies of scale." Andrew Wilson further observes consolidation was in principle a "good idea" for the industry. "It allowed companies to gain skilled assets that otherwise will take years to develop in-house. This was one way for companies to consolidate a fragmented industry and to gain resources to scale-up and grow." In general this strategy has worked for numerous capital-intensive industries, but the localization industry is a knowledge-based service that depends heavily on its human capital.

\section{DNA Media's Markets and Products}

In 1999, DNA Media provided localization services to five major market segments: (1) software application developers, (2) government and general, (3) multimedia publishers and developers (CD-ROM, DVD), (4) versioning for broadcasters and recording studios, and (5) firms requiring software design and engineering services. The most profitable services are software design and engineering, and video versioning while the least profitable segments are general work and multimedia localization. However, software application localization, and government and general localization contracts are the largest contributors to total revenues. A breakdown of the five market segments in which DNA Media participates appears in Table 3.

The financial breakdown of the company can be found in Appendix 6. The company experienced 2 years of consecutive sale revenue growth of 22 percent and 28 percent in 1999 and 2000, respectively. The growth in services, particularly in Web-related applications and content services, prompted Steven to hire additional management, and increased the budget for marketing and R\&D in preparation for anticipated growth in the E-commerce industry for the coming year. With gross profits growing during this period, Steven was particularly concerned about the rise in production costs and the additional managerial expenses on the company's earnings.

Table 3 DNA Media Market Breakdown.

\begin{tabular}{|l|l|l|l|l|l|}
\hline & $\begin{array}{l}\text { Software } \\
\text { Application }\end{array}$ & $\begin{array}{l}\text { Multimedia } \\
\text { publishers and }\end{array}$ & $\begin{array}{l}\text { Broadcasters } \\
\text { and recording }\end{array}$ & $\begin{array}{l}\text { Software } \\
\text { design and }\end{array}$ & $\begin{array}{l}\text { Government } \\
\text { and General }\end{array}$ \\
\hline
\end{tabular}




\begin{tabular}{|l|l|l|l|l|l|}
\hline & Developers & developers & $\begin{array}{l}\text { studios } \\
\text { (versioning) }\end{array}$ & $\begin{array}{l}\text { engineering } \\
\text { services }\end{array}$ & \\
\hline $\begin{array}{l}\text { Projected Reve- } \\
\text { nue for 1999 Cdn }\end{array}$ & $\$ 750,000$ & $\$ 400,000$ & $\$ 300,000$ & $\$ 300,000$ & $\$ 600,000$ \\
\hline $\begin{array}{l}\text { Percentage con- } \\
\text { tribution }\end{array}$ & $32 \%$ & $17 \%$ & $13 \%$ & $13 \%$ & $25 \%$ \\
\hline $\begin{array}{l}\text { Number of Key } \\
\text { Customers }\end{array}$ & $10-12$ & $5-6$ & $4-5$ & 10 & 20 \\
\hline $\begin{array}{l}\text { Sample } \\
\text { Customers }\end{array}$ & $\begin{array}{l}\text { Cognos } \\
\text { Seagate } \\
\text { Red Brick }\end{array}$ & $\begin{array}{l}\text { Dorling - } \\
\text { Kindersley } \\
\text { Radical }\end{array}$ & NHK & Nikon cameras & \\
\hline $\begin{array}{l}\text { Sector } \\
\text { Attractiveness }\end{array}$ & $\begin{array}{l}\text { Key to future } \\
\text { growth. }\end{array}$ & $\begin{array}{l}\text { Important for } \\
\text { future growth }\end{array}$ & $\begin{array}{l}\text { Considerable } \\
\text { potential in } \\
\text { DVD segment. }\end{array}$ & $\begin{array}{l}\text { Area of high } \\
\text { untapped po- } \\
\text { tential. }\end{array}$ & $\begin{array}{l}\text { Government cut- } \\
\text { backs will nega- } \\
\text { tively affect } \\
\text { growth; limited } \\
\text { profitability }\end{array}$ \\
\hline Price Sensitivity & Moderate & $\begin{array}{l}\text { Least sensitive } \\
\text { to price; may } \\
\text { be due to com- } \\
\text { plexity of } \\
\text { projects }\end{array}$ & Moderate & $\begin{array}{l}\text { Very sensitive to } \\
\text { price; highly com- } \\
\text { petitive segment }\end{array}$ \\
\hline
\end{tabular}

In 1998, the majority of DNA Media's customers were located in Canada (50 percent), particularly in Eastern Canada. The market share is further broken down to Japan ( 25 percent), the USA (15 percent) and Europe (10 percent). Given the strong Asian language expertise and history of the company, it is not surprising that Japan was the second largest contributor to the company's revenues.

Asian languages are DNA Media's area of expertise and contributed to over 60 percent (50-60 percent Japanese and 10 percent Chinese) of the company's revenues in 1998. Additionally, Asian languages like Japanese and Chinese require "double-byte encoding" which is technically more complicated than the systems used for European languages. Although European languages contributed 30-40 percent of revenues (1998), it is not a high margin service due to the high availability of expertise and conventional level of computer programming difficulty.

Although the "core" localization business has a lot of potential growth with the expansion of the Internet, communications and global trade, profits are very narrow. Each job is a customized job, consuming the time of skilled personnel and thereby constraining the ability to increase both profits and revenues. The challenge facing DNA Media will be to find ways to squeeze profits from business operations, and to accommodate development of new products and services.

Andrew and Mick at DNA Media both agree with Jim's points and add, "the language translation component is the least profitable part of the localization business. It is also most subject to error, most subjective to evaluate, is normally outsourced at commodity prices, and is the "least-liked" part of the business. A client may read the result and not like it because it does not "feel" right. According to Jim, translation gross margins are typically 25 to 35 percent, but the net margin can quickly disappear with unexpected revisions. The best margins are in consulting, engineering, testing, content management, and design of systems for managing content."

\section{Key Options and Challenges for DNA Media}

The main goals of the business plan are to achieve (1) long-term competitive advantage, (2) improved profitability, (3) strong revenue growth, and (4) control of the company while seeking new financial backing. Steven Forth sees three key areas of focus for DNA Media in the short to medium term.

1. Ensuring Profitability - Limited growth rates are likely due to cash flow restrictions, even though DNA Media is ideally positioned for the convergence of digital media. The company has relied on debt financing to grow the company. Corporate revenues have risen from $\$ 1.7$ million (1997) to $\$ 2.3$ million (1998), but the profit margin has declined during this period. Steps were taken in 1998 to implement a comprehensive 
project management system to control costs, improve use of resources and to match capacity with growth. But there is significant competition from consolidation in the industry, as well as competition from aggressive companies that are expanding both geographic reach and market share. DNA Media must be concerned about retaining its customers and winning clients away from other companies.

2. Growth Strategies - DNA has a variety of choices in order to expand the company. First, there is growth by acquisition. This may be the quickest way to expand DNA Media to $\$ 10$ million by 2003 . However, the company does not have the resources for acquisitions and for integrating the organizations together. Second, strategic partnering may be the answer. DNA Media can partner with vendors, customers, and suppliers. This will involve financial transaction for services, and possible exchange of some ownership equity. Alliances may be formed with other mid-sized companies. This allows smaller players the opportunity to compete with bigger players for high profile projects. Third, there can be growth by geographic expansion. DNA Media lacks location diversity, and it has hurt the company's growth internationally. DNA Media's management had discussed opening satellite (one-person) offices in Eastern Canada, SE Asia and the USA to establish a presence and to test the market.

3. Development of New Products and Services - DNA Media could introduce new high-value added services or business models like content management, development and distribution. As one solution, DNA Media can market itself as a full-service localization company, and move away from only language translation. Alternately, DNA Media can aim to differentiate from competitors, and concentrate on a focused market niche. Based on DNA Media's strengths (available technology resources; skilled staff; Vancouver's high technology environment), a likely target market would be multimedia software applications. DNA has experience and skilled resources with technology, visual materials and new media content. In this vein, Steven has considered the development of a new product in eTraining and eLearning. The business model is based on Application Service Provider (ASP) technology that allows centralized control and content management. The object-based data architecture DNA Media plans to use will make the system extremely customizable and allows the system to track learning progress and users' competencies. Steven agrees with his management team that the eTraining/eLearning "transformation strategy" is a high-risk plan, but there is tremendous upside considering the recent strides in the development of Application Service Provider (ASP) technology. This can enable the company to move from a professional services firm to a technology platform vendor with a professional service component. Core assets for this new service will be knowledge management, client relationship management, and the multilingual platform technology that DNA Media will maintain and support. Niche markets will initially consist of the company's existing client base, and providing training for channel partners and end-users over the Internet in multiple languages in Internet time. Target customers are large technology companies looking for customizable solutions, ongoing training for customer support, and an international market presence. The ASP platform is ideal for employee training and will generate revenues from hosting, managing content, and attracting third party content providers and partners. DNA Media can be clearly positioned as a solution facilitating collaboration between clients and contractors.

Steven has scheduled a meeting to discuss the above options with his management team. Jim Eagles expressed his view that DNA Media must make a paradigm shift in its thinking if the company is to grow. He used the "razor blade" analogy to explain this shift in strategy and business model. According to Jim, "there is a need for DNA Media to break the mindset that the company is just selling razor blades. The company is really selling valueadded services and products that make the person look better... like a shave, a hair cut, or a facial". The question is, how can DNA Media best make this happen?

DNA Media is behind in its four-year plan. The investment in management tools has helped control costs, but the company will not meet this quarter's profit targets due to a small over-investment in new technology and staff. New growth strategies and value-added services could well be ideal ways for DNA Media to distinguish itself from its competitors.

So, in the area of profitability, can DNA continue to rely on debt financing? Or what other ways might there be to control costs while increasing revenues? How might various growth strategies figure into this option? Could alliances or acquisitions work, and how could this contribute to the revenue stream or to global expansion as a result?

And what exactly should be the new products and services? Steven has thought about this new ASP-based 
service again and again, and is a little concerned. DNA Media's core competencies are in localization, SE Asian language translation, consulting, testing, application software and Web-based technologies for B2B and B2C. However, DNA Media's perceived core competency is culture and language. Clients may not consider them to be a technology company.

Steven recalled a memo he received last month from Mick McCallister, his VP of Technology. Mick brought to his attention the November 11, 2000 Lernout \& Hauspie Mendez (L\&H) Speech Products press release stating that the company just filed a Chapter 11 petition for reorganization protection under the U.S. bankruptcy code, and will file a request for a concordant reorganization under Belgian law. L\&H was one of the leaders in the speech and translation technology niche in the industry. It now appears that high technology translation software solutions may not be the "silver-bullet, killer application" for the software localization industry. To add to this negative momentum, a recent issue of The Localization Industry Standards Association newsletter featured an interview with the CEO of SimulTrans, Mark Homnack, who predicted that the localization industry would be littered with bankrupted globalization technology companies by the end of $2001 .{ }^{9}$ Would a more conservative approach be the right thing to do under this pessimistic economic outlook than an innovative expansion, or transformation in the product and service area?

It is now time for Steven to meet with his management team. What must Steven do to put the company back on track for its revenue and profit targets for 2003? Can the expansion strategies be viable given consolidation in the industry? Are there legitimate concerns about the ASP business model, or is this just another case of "cold feet"?

${ }^{9}$ Ibid. 


\section{Appendix 1 - Chronology of DNA Media}

The following chronology outlines the developmental steps of the company.

1989 Steven Forth returns to Canada after 10 years in Japan as an analyst and computer consultant to raise his family.

1990 Steven Forth and two partners founded Fact Media International (FMI). The business offered Japanese translation services for clients in North America and Japan.

1992 FMI expands its service range by becoming the first company in Vancouver, Canada to offer Japanese desktop publishing services.

1993 FMI expands into video versioning (i.e. dubbing) services for corporate and production companies. FMI also expands into software localization by initially focusing on modifying existing English graphics applications for use in Japanese.

1994 FMI invests in DATT North America Multimedia Inc, a joint Canadian-Japanese venture in multimedia production. FMI creates Japanese versions of all DATT's productions including the acclaimed CD-ROM version of "The Silk Road".

1995 Milestone year. FMI undergoes corporate re-engineering from a bicultural (Japanese and English) to a multicultural organization (expanding into Chinese and European languages). First bank financing received; prior to that the company was financed out of pocket. FMI expands into multiple languages, multimedia development and television product work (versioning). The company's growth is driven by demand for localization services in international markets, affordability of computer technology and growth of company's internal resources.

1996 FMI does not participate in industry consolidation that led to the emergence of powerful companies like Alpnet, BGS, L\&H and Lionbridge.

1997 Milestone year. In hindsight, a major mistake is not seeking equity financing as an alternative to bank financing which stifled the growth of the company. Steven feels the company was uniquely "packaged" (multilingual development package was more valuable than a straight localization package), has a distinct market position, and can grow independently. The Japanese market collapses, although it did not affect service contracts at the time. FMI reorganizes its corporate structure (refer to the Figure below) and the holding company was called DNA Media Group. The CD-ROM market collapses. Without a viable revenue model, this market segment for DNA Media Group was not sustainable without equity financing where several years of financial losses can be tolerated until the company establishes itself in the market.

Figure 1. DNA Corporate Structure 1997

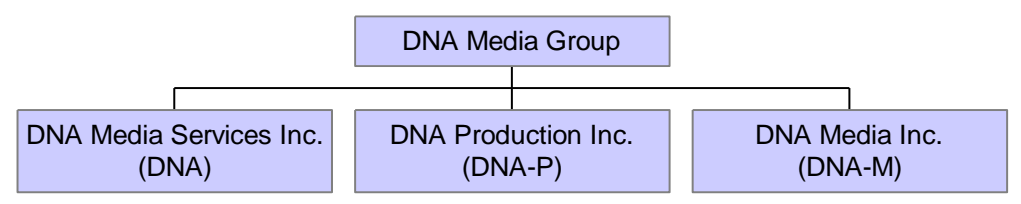

1999 Milestone year. DNA Media Group tries to get equity financing from venture capitalists but they want a "pure play". As a result, DNA Media Group re-organizes and spins off "ThoughtShare" as a separate company. This group contributed to about 10 percent of DNA Media's revenues. Equity financing is received for ThoughShare. The need for global networking to penetrate the global market is realized.

2000 A new operating company is established in January 2000 called DNA Media Inc. All assets and people from DNA Media Services are transferred to DNA Media Inc. DNA Productions (DNA-P) is put into hibernation. CD-ROM products are unsuccessful in the market. DNA Media Inc. initiates a "transformation" from a "service provider" to a "technology vendor plus professional services provider". This includes higher value services in client relationship building; technology platform in the general area of multilingual learning over the Internet (ASP model); training applications for channel partners; and content management. The reasons for these changes are to concentrate on core competency, established relationships, and in-house expertise. DNA Media Inc. invests heavily in technology and management, but this has resulted in a small loss for the company in fourth quarter of 2000 . 
Appendix 2 -DNA Organizational Structure - 1997

Adapted from: Edward Person, August 1998

\begin{tabular}{|c|c|c|c|c|}
\hline 1997 & $\begin{array}{l}\text { DNA Media } \\
\text { Group (DMG) }\end{array}$ & $\begin{array}{l}\text { DNA Media Ser- } \\
\text { vices Inc. (DNA) }\end{array}$ & $\begin{array}{l}\text { DNA Productions } \\
\text { Inc. (DNA-P) }\end{array}$ & $\begin{array}{l}\text { DNA Media Inc. } \\
\text { (DNA-M) }\end{array}$ \\
\hline $\begin{array}{l}\text { Main Corpo- } \\
\text { rate Function }\end{array}$ & $\begin{array}{l}\text { Holding company } \\
\text { owns all assets (in- } \\
\text { tellectual property, } \\
\text { financial assets, } \\
\text { physical assets) } \\
\text { and is responsible } \\
\text { for financing, go- } \\
\text { verance and over- } \\
\text { all group strategy }\end{array}$ & $\begin{array}{l}\text { Provides design, } \\
\text { engineering, pro- } \\
\text { duction and locali- } \\
\text { zation services (the } \\
\text { "core" capabilities } \\
\text { of FMI) }\end{array}$ & $\begin{array}{l}\text { Responsible for } \\
\text { the development of } \\
\text { products across } \\
\text { key media. }\end{array}$ & $\begin{array}{l}\text { Creates intellectual } \\
\text { property (content?) and } \\
\text { maximizes the long- } \\
\text { term value and revenue } \\
\text { generation. }\end{array}$ \\
\hline Products & N/A & $\begin{array}{l}\text { Media versioning } \\
\text { and software loca- } \\
\text { lization. Experts } \\
\text { in interface design, } \\
\text { translation, graphic } \\
\text { design, program- } \\
\text { ming and cross- } \\
\text { platform develop- } \\
\text { ment. }\end{array}$ & $\begin{array}{l}\text { CD-ROM, Internet } \\
\text { based projects; in } \\
\text { addition to books } \\
\text { and short TV pro- } \\
\text { grams. }\end{array}$ & $\begin{array}{l}\text { Publishing packaged } \\
\text { media materials in } \\
\text { North America, devel- } \\
\text { oping international } \\
\text { content packaging and } \\
\text { sale of rights. }\end{array}$ \\
\hline Market Focus & $\begin{array}{l}\text { Manages sales to } \\
\text { corporate and insti- } \\
\text { tutional sector. } \\
\text { Relies on word-of- } \\
\text { mouth, cold- } \\
\text { calling, and direct } \\
\text { sales techniques; } \\
\text { does not advertise. } \\
\text { Has a Web site. }\end{array}$ & $\begin{array}{l}\text { Main focus on East } \\
\text { Asian languages. } \\
\text { Market driven by } \\
\text { out-sourcing of lo- } \\
\text { calization func- } \\
\text { tions by large cor- } \\
\text { porations, increase } \\
\text { market growth in } \\
\text { international ver- } \\
\text { sion of software, } \\
\text { satellite TV (ver- } \\
\text { sioning services) } \\
\text { and DVD. }\end{array}$ & $\begin{array}{l}\text { Sells its services to } \\
\text { DNA-M and DNA. } \\
\text { DNA-M handles } \\
\text { sales of products } \\
\text { and broadcast me- } \\
\text { dia while DNA } \\
\text { handles sales to the } \\
\text { corporate and insti- } \\
\text { tutional sector. }\end{array}$ & $\begin{array}{l}\text { Education market. } \\
\text { Progressive parents } \\
\text { and empty-nesters with } \\
\text { disposable income for } \\
\text { travel. Secondary } \\
\text { market is elementary, } \\
\text { high school and post- } \\
\text { secondary institutions. }\end{array}$ \\
\hline $\begin{array}{l}\text { Long-Term } \\
\text { Strategy }\end{array}$ & $\begin{array}{l}\text { DMG to eventual- } \\
\text { ly moved to an As- } \\
\text { set Management } \\
\text { Model. }\end{array}$ & $\begin{array}{l}\text { Expected growth } \\
\text { in 1998; multi- } \\
\text { media localization } \\
\text { = 35\% per year; } \\
\text { DVD and video re- } \\
\text { lated localization = } \\
45 \% \text { per year. } \\
\text { General Transla- } \\
\text { tion = } 11 \% \text { per } \\
\text { year. }\end{array}$ & $\begin{array}{l}\text { DNA-P will even- } \\
\text { tually develop its } \\
\text { own content and } \\
\text { sources of external } \\
\text { revenue. }\end{array}$ & $\begin{array}{l}\text { Develop inventory of } \\
\text { content that can be re- } \\
\text { used. Driving force } \\
\text { behind development of } \\
\text { new concepts and IP. }\end{array}$ \\
\hline
\end{tabular}

Appendix 3 - Evolution of the Localization Industry

\section{Pre-1996}

Prior to 1996, localization was essentially a cottage industry. The largest companies earned \$US one million to \$US two million per year. Key success factors for business in this industry mainly revolved around language expertise, project management and resource management. The business model was based on charging rates for "dollars-per-word" translated. 


\section{$1996-1999$}

The industry structure and climate changed significantly during the consolidation period that began in 1996. Consolidation resulted in the emergence of very large well-capitalized players like Berlitz, Lionbridge, L\&H, Alpnet and Bowes Global Services (BGS) in a traditionally fragmented marketplace. Some drivers for consolidation were the growing equity financing market, rise of the Internet, low cost of computer technology, the trend towards outsourcing, and the growing use of non-English language on the Internet. Subsequently, the nature of the industry changed. Some of the consolidators tried to commoditize the business by reducing the business model to "penniesper-word" through the use of translation software. At the same time some companies began marketing a one-stop high-value-added service. .

\section{9 to present}

In 1999, the big players in the industry drove the next evolution of localization services by moving towards "global solutions". The large consolidated companies moved localization beyond the IT industry, and began focusing on content flows, hosted applications, databases and knowledge bases. Extensive use of tools like XML, content management and testing tools grew, allowing enterprises to leverage their translation investment by allowing content to be "re-used". Localization services grew to include translation management (e.g. Internet portals, workflow, and connectivity), multiple language real-time content on the Web, global rendering and global testing. Globalization is expected to evolve towards an integrated value chain model from the fragmented piece-meal approach to services currently being used. The business model has shifted towards an added-value service model placing emphasis on time, quality, cost, availability, subscription, platform and retainer, all in an effort to increase profit margins. The days of large software projects with large companies will slow down due to the move towards an ASP model, and open up business opportunities with small-to-medium sized enterprises (SME's). 


\section{Appendix 4 - Industry Profile for the Software Localization Industry}

\begin{tabular}{|c|c|}
\hline & General Comments \\
\hline Barrier to Entry / Exit & $\begin{array}{l}\text { High barrier to entry due to expertise needed in language, engineering, and } \\
\text { design. Capital costs moderate. } \\
\text { Shortage of specialized talent in localization. } \\
\text { Steep learning curve for new entrants. } \\
\text { Requires network of clients, and reputation to survive in service industry, } \\
\text { and this will take time to develop. } \\
\text { As industry consolidates, barriers will increase with time as global net- } \\
\text { works strengthen. }\end{array}$ \\
\hline Dominant players & Consolidators: Alpnet, BGS, L\&H Mendez, Lionbridge, Berlitz \\
\hline Breadth of Languages & $\begin{array}{l}\text { SLV (single language vendors); small size, sharp focus, small players } \\
\text { MLV; large companies especially consolidators. }\end{array}$ \\
\hline Capital Costs & $\begin{array}{l}\text { Moderate but climbing due to evolving hardware and software requirements } \\
\text { and tools. }\end{array}$ \\
\hline Pace of Technology Change & $\begin{array}{l}\text { Very high. Hardware and software tools are constantly changing. Software } \\
\text { being localized has short life cycle. } \\
\text { Distribution channels expanding; DVD, WebTV, Internet. }\end{array}$ \\
\hline Economies of Scale & $\begin{array}{l}\text { Low scalability. Each project is a customized product requiring significant } \\
\text { input from skilled workers, and the product is not scalable as volume of } \\
\text { work increases. } \\
\text { Modest scalability with marketing, advertising, infrastructure, and man- } \\
\text { agement expenditures. }\end{array}$ \\
\hline Learning Curve & $\begin{array}{l}\text { Very steep. Costs decline once expertise is gained, but it takes time to gain } \\
\text { experience and competency. } \\
\text { Translation management tools like Trados and source code management } \\
\text { tools like Corel Catalyst enable improvement in efficiencies for repetitive } \\
\text { jobs and content. Does not replace skilled personnel. }\end{array}$ \\
\hline Vendor-Client Loyalty & $\begin{array}{l}\text { Generally, vendors who do initial localization jobs will do projects for the } \\
\text { life of software package. There are significant pressures to win the first } \\
\text { contract with vendors. }\end{array}$ \\
\hline Industry Profitability & Low to moderate. \\
\hline Industry Driving Forces & $\begin{array}{l}\text { Competitive rivalry is moderate due to } 30 \% \text { annualized industry growth } \\
\text { rate. However, consolidators will be more competitive and dominating as } \\
\text { the industry matures. } \\
\text { Power of suppliers; shortage of skilled personnel - growth in demand out- } \\
\text { strips supply of people available to do projects. } \\
\text { Power of buyers; top ten industry leaders like IBM, Microsoft and Oracle } \\
\text { dominate } 50 \% \text { of the market. }\end{array}$ \\
\hline
\end{tabular}

Adapted from: Edward Person, August 1998 


\section{Appendix 5 - Top-Tiered Consolidated Companies}

\begin{tabular}{|c|c|}
\hline $\begin{array}{l}\text { Top Tiered Compa- } \\
\text { ny }\end{array}$ & Characteristics \\
\hline Berlitz & $\begin{array}{l}\text { Worldwide market leader in language instruction and translation services. Only } \\
\text { "brand name" in the industry. } \\
1997 \text { Total Revenues of } \$ 366 \mathrm{~m} \text {, and software localization contributing } 22 \% \text { or } \\
\$ 80.5 \mathrm{~m} \\
3 \text { divisions: Language Instruction, Translation Services (software localization, in- } \\
\text { teractive media, translation, general interpretation) and Publishing. } \\
\text { Translation Services are focused on IT, automotive, medical technology and tele- } \\
\text { communications market segments. } \\
\text { Strong in international scope of operations ( } 325 \text { training centres, } 200 \text { languages). } \\
\text { Weak in not forseeing market growth for software localization, and has fallen be- } \\
\text { hind competitors in this area. }\end{array}$ \\
\hline $\begin{array}{l}\text { BGS (Bowne Global } \\
\text { Services) }\end{array}$ & $\begin{array}{l}\text { Became a major localization player in less than } 2 \text { years due to consolidation. Refo- } \\
\text { cused business on "Empowering Information"; distributing client's information to } \\
\text { any audience, in any language, anywhere in the world. } \\
\text { View service as a standardized end product. Believes clients like consistent content } \\
\text { across all locations. } \\
\text { Basis of competition is on quality of service, project management skills and breadth } \\
\text { of languages offered. } \\
\text { In } 1998 \text {, purchased Linguistix, a multi-language machine translation tool. } \\
\text { Strong: it is premier player in software localization. Provides quality and breadth of } \\
\text { services. } \\
\text { No significant weaknesses. }\end{array}$ \\
\hline Alpnet & $\begin{array}{l}\text { Views service as a standardized end product. Believes clients like consistent con- } \\
\text { tent across all locations. } \\
\text { Basis of competition is quality of service, project management skills and breadth of } \\
\text { languages offered. } \\
\text { Founded in } 1980 \text { in Salt Lake City, Utah. } \\
3 \text { product lines: localization ( } 45 \% \text { revenues), documentation ( } 40 \% \text { revenues) and } \\
\text { translation ( } 15 \% \text { revenues). } \\
\text { Alpnet targets market niches in ERP, Computer-based training and the global au- } \\
\text { tomotive sector. } \\
\text { Strong in its size and global network that includes partnerships with Compaq, Intel, } \\
\text { Dell, Baan Computer, Oracle, Lotus and Chrysler. } \\
\text { Weak in offering consistent quality and reliance on aging translation technology } \\
\text { that was developed in-house and has not kept up with current technology offerings. }\end{array}$ \\
\hline $\begin{array}{l}\text { Lernout \& Hauspie } \\
\text { Mendez }\end{array}$ & $\begin{array}{l}\text { L\&H parent company is technology leader in advanced speech technology and } \\
\text { translation services. } \\
\text { Founded in } 1987 \text { in Belgium. } \\
4 \text { divisions: Core Speech Technologies / Dictation / Translation and Localization / } \\
\text { Language Technologies. } \\
\text { The T\&L group, known as L\&H, is among the top tier localization vendors. } \\
\text { Customers include Microsoft, IBM, SAP, Exxon, Lucent, and Medtronic. } \\
\text { L\&H Mendez contributed } 32 \% \text { or } \$ 31.6 m \text { (1997) to parent company's revenues. } \\
\text { Strong presence in Latin America, part ownership by Microsoft, L\&H translation } \\
\text { technologies. } \\
\text { Weak: historical reliance on European languages, and lack exposure to SE Asia. }\end{array}$ \\
\hline Lionbridge & $\begin{array}{l}\text { Founded in the } 1980 \text { s in the Netherlands. } \\
\text { Focused on providing the technology and linguistic skills necessary for localization } \\
\text { services. } \\
\text { Customers include Microsoft, Lotus, Baan, Sun, Parametric Technologies, and Tra- } \\
\text { dos. } \\
\text { Lionbridge targets Financial Applications, Operating Systems and Web Technolo- }\end{array}$ \\
\hline
\end{tabular}




\begin{tabular}{|l|l|}
\hline gies. & Strong: management team with experience in Fortune 500 technology companies; \\
employee ownership; value-added relationship with Trados. & About 50\% of revenues came from Web-based activities and products, while the \\
& other 50\% came from operating systems and desktop applications. \\
& Weak: poor integration of recently acquired Japanese Language Services in 1997 \\
& resulted in inefficient operations and poor customer satisfaction.
\end{tabular}

Adapted from: Edward Person, August 1998

Appendix 6: Financial Statement

\begin{tabular}{|c|c|c|c|c|c|c|c|}
\hline \multirow{2}{*}{ Revenues } & & \multicolumn{2}{|r|}{1998} & \multicolumn{2}{|r|}{1999} & \multicolumn{2}{|r|}{2000} \\
\hline & & & & & & & \\
\hline Linguistic & General & $\$$ & 250,000 & $\$$ & 275,000 & $\$$ & 250,000 \\
\hline & Application & $\$$ & 550,000 & $\$$ & 700,000 & $\$$ & 800,000 \\
\hline & Web Application & $\$$ & - & $\$$ & 50,000 & $\$$ & 120,000 \\
\hline & CD-ROM & $\$$ & 200,000 & $\$$ & 150,000 & $\$$ & 75,000 \\
\hline & Web Content & $\$$ & 100,000 & $\$$ & 175,000 & $\$$ & 200,000 \\
\hline Design & General & $\$$ & 100,000 & $\$$ & 75,000 & $\$$ & 60,000 \\
\hline & Application & $\$$ & 75,000 & $\$$ & 90,000 & $\$$ & 110,000 \\
\hline & Web Application & $\$$ & 50,000 & $\$$ & 100,000 & $\$$ & 120,000 \\
\hline & CD-ROM & $\$$ & 100,000 & $\$$ & 75,000 & $\$$ & 30,000 \\
\hline & Web Content & $\$$ & 75,000 & $\$$ & 150,000 & $\$$ & 125,000 \\
\hline Engineering & General & $\$$ & - & $\$$ & - & $\$$ & - \\
\hline & Application & $\$$ & 350,000 & $\$$ & 400,000 & $\$$ & 800,000 \\
\hline & Web Application & $\$$ & - & $\$$ & 200,000 & $\$$ & 425,000 \\
\hline & CD-ROM & $\$$ & 200,000 & $\$$ & 100,000 & $\$$ & 30,000 \\
\hline & Web Content & $\$$ & 50,000 & $\$$ & 100,000 & $\$$ & 250,000 \\
\hline Consulting & & $\$$ & 100,000 & $\$$ & 50,000 & $\$$ & 60,000 \\
\hline Other & & & & & & & \\
\hline Total & & $\$$ & $2,200.000$ & $\$$ & 2.690 .000 & $\$$ & $3,455,000$ \\
\hline & & & & & & & \\
\hline Cost of Sales & & & & & & & \\
\hline External Production & & $\$$ & 570,000 & $\$$ & 685,000 & $\$$ & 734,500 \\
\hline Internal Production & & $\$$ & 920,000 & $\$$ & $1,124,000$ & $\$$ & $1,483,000$ \\
\hline Sales & & $\$$ & 220,000 & $\$$ & 295,900 & $\$$ & 414,600 \\
\hline Gross Profit & & $\$$ & 490,000 & $\$$ & 585,100 & $\$$ & 822,900 \\
\hline Operating Costs & & & & & & & \\
\hline Management & & $\$$ & 225,000 & $\$$ & 250,000 & $\$$ & 580,000 \\
\hline Marketing & & $\$$ & 10,000 & $\$$ & 75,000 & $\$$ & 150,000 \\
\hline Office & & $\$$ & 120,000 & $\$$ & 180,000 & $\$$ & 190,000 \\
\hline R\&D & & $\$$ & 50,000 & $\$$ & 250,000 & $\$$ & 200,000 \\
\hline Total & & $\$$ & 405,000 & $\$$ & 755,000 & $\$$ & $1,120,000$ \\
\hline EBITDA & & $\$$ & 85,000 & $\$$ & $(169,900)$ & $\$$ & $(297,100)$ \\
\hline
\end{tabular}


